\title{
2p24 Gain Region Harboring MYCN Gene Compared with MYCN Amplified and Nonamplified Neuroblastoma
}

\section{Biological and Clinical Characteristics}

\begin{abstract}
Marta Jeison, ${ }^{*}$ Shifra Ash, ${ }^{\dagger}$ Gili Halevy-Berko, ${ }^{*}$ Jacques Mardoukh, ${ }^{*}$ Drorit Luria, ${ }^{\neq}$ Smadar Avigad, ${ }^{\dagger \S}$ Galina Feinberg-Gorenshtein, ${ }^{\S}$ Yacov Goshen, ${ }^{\dagger}$ Gabriel Hertzel, ${ }^{\top}{ }^{\top}$ Joseph Kapelushnik,,$^{\|}$Ayelet Ben Barak, ** Dina Attias, ${ }^{\dagger \dagger}$ Ran Steinberg, ${ }^{\neq \neq}$Jerry Stein, ${ }^{\dagger}$ Batia Stark, ${ }^{* \dagger}$ and Isaac Yaniv ${ }^{\dagger \S}$

From the Cancer Cytogenetic Laboratory, ${ }^{*}$ the Pediatric Hematology Oncology Department, ${ }^{\dagger}$ the Flow Cytometry Laboratory of the Felsenstein Medical Research Center, ${ }^{*}$ the Molecular Oncology Laboratory of the Felsenstein Medical Research Center, ${ }^{\S}$ and the Department of Pediatric Surgery, ${ }^{\text {\# }}$ of the Schneider Children's Medical Center of Israel, Petah Tikva; the Sackler School of Medicine, Tel Aviv University, Tel Aviv; the Pediatric Oncology Unit, " Haemek Medical Center, Afula; the Pediatric Day Care Unit," Soroka University Medical Center, Faculty of Health Sciences, Ben-Gurion University of the Negev, Beer Sheva; the Department of Pediatric Hematology Oncology, ** Meyer Children's Hospital, Rambam Health Care Campus, Haifa; the Division of Pediatric Hematology/Oncology, ${ }^{\text {t+ }}$ Bnei Zion Medical Center, Bruce Rappoport Faculty of Medicine, Technion Institute, Haifa, Israel
\end{abstract}

Although the role of $M Y C N$ amplification in neuroblastoma is well established, the biological and clinical characteristics of the $2 p$ gain region harboring the MYCN gene remain unclear. The aim of this study was to compare the biological and clinical characteristics of these tumors with MYCN amplified and nonamplified neuroblastoma and to determine their impact on disease outcome. Samples from 177 patients were analyzed by fluorescence in situ hybridization, including $M Y C N, 1 p, 17 q$, and $11 q$ regions; $2 p$ gain was identified in 25 patients, MYCN amplification in 31, and no amplification in 121 patients. Patients with $2 p$ gain had a significantly worse 5-year event-free survival rate than patients with no $M Y C N$ amplified
$(P<0.001)$, and an intermediate 5-year overall survival rate difference existed between the $M Y C N$ amplified tumors $(P=0.025)$ and nonamplified $(P=0.003)$ groups. All of the $2 p$ gain samples were associated with segmental and/or numerical alterations in the other tested regions. The presence of segmental alterations with or without $M Y C N$ amplification was recently found to be the strongest predictor of relapse in a multivariate analysis. The results of the present study suggest that the determination of $M Y C N$ gene copy number relative to chromosome 2, when evaluating MYCN status at diagnosis, may help to reveal the underlying genetic pattern of these tumors and better understand their clinical behavior. (Am J Pathol 2010, 176:2616-2625; DOI: 10.2353/ajpath.2010.090624)

Neuroblastoma is an embryonal tumor of childhood originating from cells of the sympathetic neuroectodermal system. Its clinical behavior varies widely, from spontaneous regression in infants or maturation to benign ganglioneuroma in older patients, to a disseminated aggressive chemoresistant tumor with a fatal outcome. A large spectrum of heterogeneous genetic changes underlies this biological diversity. ${ }^{1,2}$

The clinical behavior of human neuroblastoma tumors may be predicted by the analysis of a panel of prognostic factors: patient age at diagnosis, ${ }^{3}$ disease stage, ${ }^{4}$ tumor histopathology (favorable/unfavorable), ${ }^{5}$ DNA index,,${ }^{6,7}$ and MYCN status. ${ }^{8,9}$ In addition, controversial studies have indicated that $1 p$ deletion ${ }^{10-12}$ and $17 q$ gain are also factors of poor prognosis. ${ }^{13-16}$ Deletions in chromo-

Accepted for publication February 4, 2010.

Address reprint requests to Marta Jeison, Ph.D., Ca-Cytogenetic Lab, Pediatric Hematology Oncology Department, Schneider Children's Medical Center of Israel. Kaplan St. 14, 49202 Petah Tikva, Israel. E-mail: martaj@clalit.org.il. 
some arms $3 p$ and $11 q$ have been defined as poor prognostic markers in localized and 4 s neuroblastoma. ${ }^{17} \mathrm{~A}$ deletion of the $11 \mathrm{q}$ region is also associated with a poor outcome, particularly in Neuroblastoma without MYCN amplification. ${ }^{18,19}$ Lastowska et al (2007) ${ }^{20}$ reported that the expression of genes localized in a novel region on $4 p$ correlated with the DNA copy number and survival. According to the last report of the International Neuroblastoma Risk Group, regression analysis of the data base confirmed the prognostic significance of MYCN amplification, deletions on 11q, and ploidy, in addition to age and disease stage. ${ }^{21}$ In patients without MYCN amplification, a genomic profile characterized by any segmental alteration (partial chromosome gain and loss) adds prognostic information to these clinical markers. ${ }^{22}$ In a recent study, multivariate analysis, taking into account the overall genetic profile of NB tumors, in addition to the well known genetic and clinical markers with prognostic significance, the presence of segmental alterations with or without MYCN amplification was found to be the strongest predictor of relapse. ${ }^{23} \mathrm{~A}$ novel marker, telomere length, has recently been suggested to be added to the conventional prognostic indicators. ${ }^{24}$

MYCN is a cellular proto-oncogene of the myc family of transcription factors that maps to the short arm of chromosome 2 (band 2p24). ${ }^{25}$ MYCN amplification occurs in $20 \%$ to $30 \%$ of primary neuroblastoma. During amplification, genetic material from the chromosomal region is transposed to extrachromosomal double minutes or to intrachromosomal homogeneously staining regions. The tumorigenic potential of this process is most probably a consequence of an increase in gene dose, as mutations within the gene have not been detected. ${ }^{26}$

For several years, we have been characterizing neuroblastoma tumors by fluorescence in situ hybridization (FISH), paying special attention to the MYCN copy number, following the recommendations of the European Neuroblastoma Quality Assessment (ENQUA) group. ${ }^{27}$ FISH makes it possible to rapidly and sensitively detect single-copy DNA sequences in metaphase and interphase nuclei. Additional advantages of this method include reduced tissue requirement and high versatility in determining the nature of the amplification unit (double minutes or homogeneously staining regions). Furthermore, because the copy number can be determined at the single-cell level, FISH has the capability to demonstrate intercellular heterogeneity in MYCN amplification within a given tumor cell population. ${ }^{28,29}$ The International Neuroblastoma Risk Group Biology Committee defined $2 \mathrm{p}$ gain as equal number of MYCN and $2 \mathrm{p}$ signals, exceeding $2 \mathrm{q}$ signals in mostly one or two copies. A balanced ratio between the MYCN specific signals and the signal numbers of the reference probe on the chromosome $2 \mathrm{q}$ arm defines a MYCN nonamplified tumor (MYCN normal status). An over fourfold increase in the MYCN signal number relative to chromosome $2 \mathrm{q}$ indicates a MYCN amplified tumor. ${ }^{30}$ Although the association of MYCN amplification with poor prognosis is well established, the biological and clinical characteristics of $2 \mathrm{p} /$ MYCN gain have not been clearly defined. To the best of our knowledge, only three publications to date have ad- dressed these findings and their possible influence on the disease outcome, but no definitive conclusions were reached. ${ }^{31-33}$ In addition, several case reports have been published on the management of tumors with lowlevel gain in the $M Y C N$ region. ${ }^{33,34}$

The aim of the present retrospective study was to investigate the cytogenetic and clinical characteristics of patients with neuroblastoma showing 2p/MYCN gain and to compare the findings with $M Y C N$-amplified neuroblastoma and neuroblastoma with a balanced number of MYCN gene copies, and explore a possible impact on outcome.

\section{Materials and Methods}

\section{Patients}

Samples from 177 patients with neuroblastoma who were diagnosed and treated in seven centers in Israel between 1993 and 2007 were analyzed at the Cancer Cytogenetic Laboratory of the Pediatric Hemato/Oncology Department of Schneider Children's Medical Center of Israel. One hundred fifty-two samples were derived from tumors and 25 from involved bone marrow; 169 were analyzed at diagnosis and eight after relapse. The study group included 102 male patients and 75 female patients of median age 2.9 years at diagnosis (range, 0 to 17 years). Fifty-three patients were under 1 year old, and 124 were over 1 year old. Stage was assigned according to the International Neuroblastoma Staging System ${ }^{4}$ as follows: stage 1, 26 patients (15\%); stage 2, 19 (10\%); stage 3, 37 (21\%); stage 4, 82 (47\%); and stage 4s, 13 (7\%). Median follow-up was 80 months (range, 0.23 to 200 months). Three patients were lost during follow-up and were included only in the analysis of biological characterization.

Treatment consisted of local protocols including surgery, intensive chemotherapy, and myeloablative therapy with stem cell rescue for high risk patients. Forty-nine high risk patients are included in the Société Internationale d'Oncologie Pédiatrique Europe Neuroblastoma, High Risk Neuroblastoma 1 (SIOPEN HRNBL1) study.

\section{Fluorescence in Situ Hybridization}

FISH was performed on cytogenetic slides or touch imprints from fresh tumor tissue. Interphase tumor nuclei were screened for MYCN copy number in the whole cohort with a MYCN DNA (2p24) probe (Oncor, Gaithersburg, MD; Vysis, Downers Grove, IL), together with a reference gene such as LAF (2q11) or centromere of chromosome 2 (Qbiogene, Illkirch, France; Kreatech, Amsterdam, the Netherlands; Vysis). The status of three additional genetic parameters was also analyzed: in 174 samples $1 p$ region, with CEP 1 (satellite II/III) band 1q12 for the centromeric region of chromosome 1 (Vysis) and midisatellite D1Z2, for the 1p36 locus (Oncor/Qbiogene, Kreatech); in 155 samples 11q region, with CEP $11(\alpha$-satellite, D11Z1) combined with MLL (11q23.3; ONCOR, Vysis); and in 169 samples 17q region, with CEP17 ( $\alpha$-satellite, D17Z1) for centromere 17 or band 17p11.1-q11.1 locus (Vysis) combined with 17q probe 

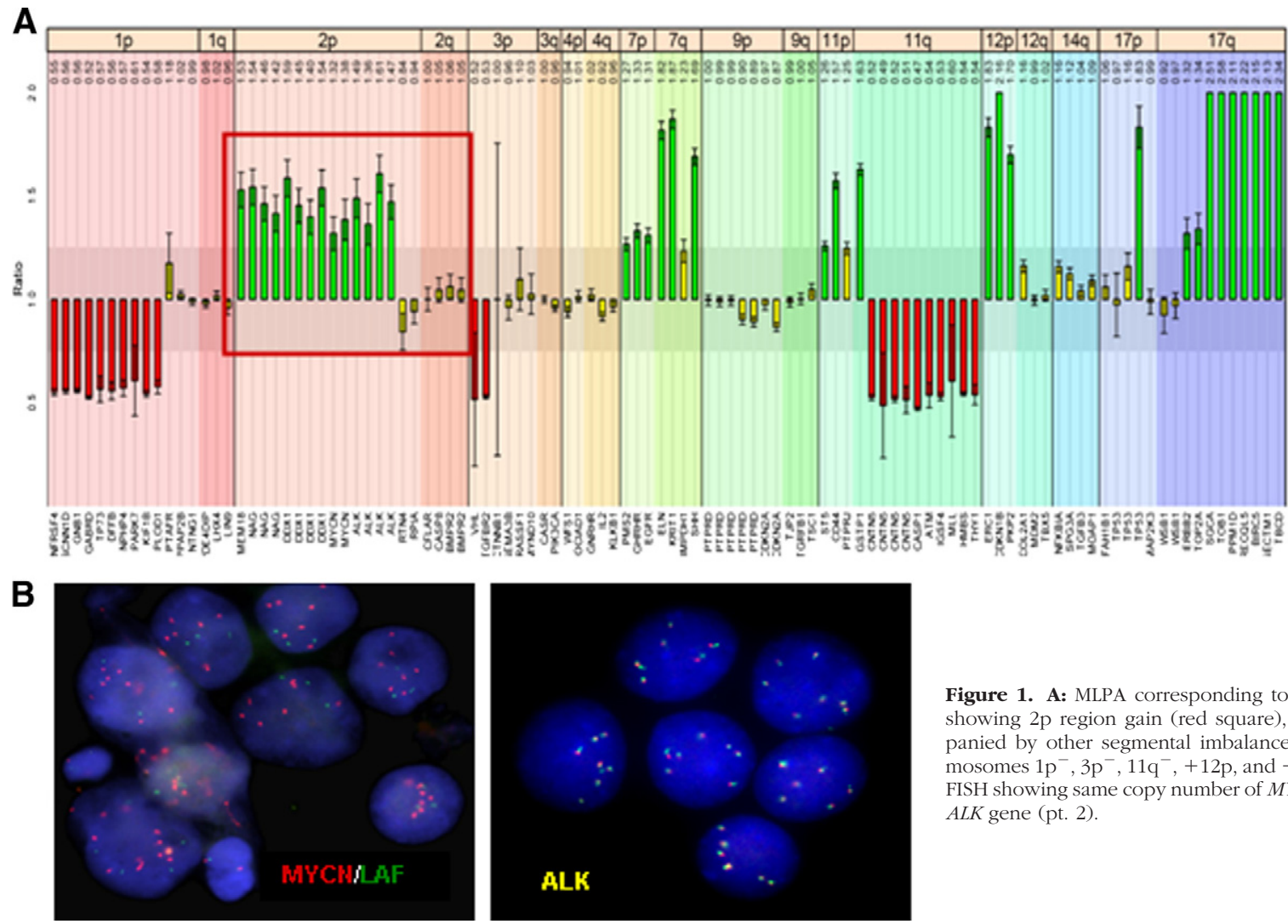

Figure 1. A: MLPA corresponding to pt. 171 showing $2 \mathrm{p}$ region gain (red square), accompanied by other segmental imbalances: chromosomes $1 \mathrm{p}^{-}, 3 \mathrm{p}^{-}, 11 \mathrm{q}^{-},+12 \mathrm{p}$, and $+17 \mathrm{q}$. B FISH showing same copy number of $M Y C N$ and $A L K$ gene (pt. 2).

(17q25-qter; Oncor) or telomere 17q (Vysis); two dual-color probes: LIS1/RARA, which hybridize to band 17p13.3 and 17q21.1, respectively (Vysis); and p53/mpo (17p13, 17q23) (Kreatech). FISH was performed according to the manufacturer's instructions with slight modifications, as previously described. ${ }^{35}$ An average of 200 nuclei was counted for each sample.

In cases where the relevant abnormal populations were detected only in low percentages, we performed sequential FISH analysis with different probes on the same cells for up to three consecutive hybridizations per slide. Using this strategy, we were able to confirm the tumor character of the cell population, taking advantage of the FISH technique's efficiency in detecting gene aberrations at the cellular level.

\section{Multiplex Ligation-Dependent Probe Amplification}

Multiplex ligation-dependent probe amplification (MLPA) was performed only in the MYCN gain cases to identify whether the region gained included adjacent genes in addition to the MYCN gene. With this technique, partial gains or losses in 10 different chromosomes could be identified in one experiment. ${ }^{36,37}$ We used the neuroblastoma-specific SALSA MLPA probe, which consists of three kits P251/P252/P253 (MRC-Holland, Amsterdam, the Netherlands). The P251 probe mix contains 38 probes for chromosomes 1, 3, and 11; P252 probe mix contains 36 probes for chromosomes 2 and 17; and the P253 probe mix contains 32 probes for chromosomes 4 , $7,9,12$, and 14 . Region $2 \mathrm{p}$ is covered by 16 clones from seven different genes: TMEM18, NAG, DDX1, MYCN,
ALK, RTN4, and RPIA. Each of these three probe mixes contains five control fragments in chromosomal regions rarely altered in NB. Each probe is composed of two adjacent oligonucleotides containing the target-specific sequence, a universal PCR primer, and in one of them, a stuffer sequence of unique length for each one. The procedure was performed as described by the manufacturer. Briefly, 50 to $100 \mathrm{ng}$ DNA in $5 \mu \mathrm{l}$ TE-buffer was denaturated for 5 minutes at $98^{\circ} \mathrm{C}$ and subsequently cooled down to $25^{\circ} \mathrm{C}$. After the addition of $1.5 \mu$ probe mix and $1.5 \mu \mathrm{l}$ buffer, the sample was denaturated for 1 minute at $95^{\circ} \mathrm{C}$, and the probes were allowed to hybridize for 16 hours at $60^{\circ} \mathrm{C}$. Ligation was performed for 15 minutes at $54^{\circ} \mathrm{C}$ after the addition of Ligase $-65 \mathrm{mix}$, and then heat inactivated at $98^{\circ} \mathrm{C}$ for 5 minutes. The ligation products were PCR amplified by the addition of $10 \mu \mathrm{l}$ of this ligation mixture to $40 \mu$ l PCR mixture provided by the supplier. In each set of MLPA experiments, we included at least three normal control DNA samples for data processing. PCR was performed in a T3000 Thermocycler (Whatman, Biometra) for 35 cycles. Samples were analyzed by an ABI 3100 DNA analyzer (Applied Biosystems, Foster City, CA) using the Genescan software 3.7. The results were saved as an Excel file (Microsoft Corporation, Redmond, WA, United States of America) and imported for graphical visualization to the MLPAVizard software, specially developed for the neuroblastoma kit and kindly provided by Professor Ambros and Austrian Research Centers $\mathrm{GmbH}$, Vienna, Austria. In cases when MLPA could not be performed, we used $A L K$ gene probe on 2p23 (Vysis) to confirm an enlarged region of gain on $2 p$ containing extra copies of MYCN gene. 
Table 1. FISH, DNA Index, Survival, and Outcome of the 25 Patients with $2 \mathrm{p} / \mathrm{MYCN}$ Gain

\begin{tabular}{|c|c|c|c|c|c|c|c|c|c|c|c|}
\hline \multirow[b]{2}{*}{ Pt. no. } & \multicolumn{2}{|c|}{$\begin{array}{l}\text { CEP2/MYCN } \\
\text { or } L A F / M Y C N\end{array}$} & \multicolumn{2}{|c|}{ CEP $1 / 1 p^{\dagger}$} & \multicolumn{2}{|c|}{ CEP $11 / 11 q^{\ddagger}$} & \multicolumn{2}{|c|}{$17 p / 17 q^{\S}$} & \multirow[b]{2}{*}{ DNA index } & \multirow[b]{2}{*}{ Survival (mo.) } & \multirow[b]{2}{*}{ Status } \\
\hline & Copy no." & $\%$ & Copy no. & $\%$ & Copy no. & $\%$ & Copy no. & $\%$ & & & \\
\hline \multirow[t]{2}{*}{2} & $4 / 7$ & 30 & $4 / 2$ & 30 & $4 / 2$ & 27 & $4 / 7$ & 20 & 1.93 & 16 & $\mathrm{D}$ \\
\hline & $5 / 7$ & 20 & & & & & & & & & \\
\hline 16 & $3 / 4$ & 95 & $3 / 2$ & 58 & $2 / 2$ & 99 & $4 / 4$ & 17 & 1.41 & LFU" & - \\
\hline 25 & $4 / 7$ & 80 & $4 / 3$ & 55 & $4 / 2$ & 72 & $4 / 5$ & 80 & 1.94 & 19 & D \\
\hline \multirow[t]{2}{*}{41} & $2 / 4$ & 30 & $3 / 3$ & 18 & $3 / 3$ & 34 & $3 / 3$ & 14 & 1 & 122 & A \\
\hline & $\begin{array}{l}3 / 5 \\
4 / 6\end{array}$ & & & & & & & & & & \\
\hline \multirow[t]{2}{*}{47} & $4 / 6$ & 81 & $4 / 3$ & 55 & ND & - & $4 / 6-7$ & 27 & 2 & 126 & A \\
\hline & $6 / 9$ & & & & & & & & & & \\
\hline \multirow[t]{2}{*}{58} & $2 / 4$ & 15 & $3 / 2$ & 43 & $3 / 3$ & 35 & $4 / 4$ & 15 & 1.31 & 117 & A \\
\hline & $2 / 5$ & 33 & & & & & & & & & \\
\hline \multirow[t]{2}{*}{94} & $3 / 5$ & 20 & $4 / 2$ & 36 & $4 / 2$ & 36 & $3 / 8$ & 14 & 2.03 & 49 & D \\
\hline & $4 / 5$ & 20 & & & & & $4 / 6$ & 15 & & & \\
\hline 96 & $3 / 6$ & 22 & $4 / 4$ & 50 & $3 / 2$ & 48 & $5 / 7$ & 43 & 1.92 & 32 & D \\
\hline \multirow[t]{2}{*}{118} & $2 / 3$ & 74 & $3 / 2$ & 59 & $2 / 1$ & 81 & $2 / 3-4$ & 8 & 1 & 61 & A \\
\hline & & & & & & & $3 / 4-5$ & 21 & & & \\
\hline 124 & $4 / 5$ & 98 & $3 / 3$ & 50 & $5 / 2$ & 80 & $2 / 4$ & 33 & 1.67 & 110 & D \\
\hline 132 & $2 / 3$ & 99 & $2 / 2$ & 80 & $2 / 1$ & 92 & $2 / 4$ & 100 & 1 & 23 & $\mathrm{D}$ \\
\hline \multirow[t]{2}{*}{133} & $4 / 6$ & 80 & $3 / 3$ & 30 & $3 / 3$ & 25 & $2 / 5$ & 58 & 2.06 & 37 & $\mathrm{D}$ \\
\hline & & & $4 / 4$ & 53 & $4 / 4$ & 61 & $3 / 6$ & 25 & & & \\
\hline 140 & $2 / 3$ & 30 & $2 / 2$ & 98 & $2 / 1$ & 34 & $2 / 5$ & 30 & 1 & 49 & D \\
\hline \multirow[t]{3}{*}{146} & $2 / 3$ & 23 & $3 / 3$ & 14 & $3 / 1$ & 40 & $2 / 3$ & 25 & 1.92 & 45 & $\mathrm{D}$ \\
\hline & $3 / 6$ & 22 & $4 / 4$ & 18 & $4 / 2$ & 40 & $2 / 6$ & 35 & & & \\
\hline & $4 / 6$ & 44 & & & & & $3 / 7-8$ & 35 & & & \\
\hline \multirow[t]{2}{*}{148} & $2 / 4$ & 23 & $3 / 3$ & 43 & $3 / 3$ & 76 & $4 / 4$ & 49 & 1.53 & 30 & $D$ \\
\hline & $3 / 4$ & 65 & & & & & & & & & \\
\hline 157 & $2 / 3$ & 42 & $2 / 2$ & 80 & $2 / 1$ & 40 & ND & - & ND & 39 & D \\
\hline \multirow[t]{3}{*}{159} & $2 / 4$ & 80 & $2 / 2$ & 92 & $3 / 2$ & 80 & 2/9-15 & 15 & 1.35 & 39 & D \\
\hline & & & & & & & $3 / 5-9$ & 43 & & & \\
\hline & & & & & & & $4 / 10$ & 22 & & & \\
\hline \multirow[t]{2}{*}{161} & $2 / 3$ & 29 & $2 / 2$ & 95 & $2 / 2$ & 80 & $2 / 3$ & 35 & 1 & 34 & D \\
\hline & & & & & & & $2 / 4$ & 15 & & & \\
\hline \multirow[t]{2}{*}{164} & $4 / 5-7$ & 76 & $4 / 4$ & 59 & $3 / 2$ & 59 & 2/amp & 21 & 2.07 & 21 & D \\
\hline & & & & & $4 / 2$ & 13 & 3/amp & 68 & & & \\
\hline 166 & $2 / 3$ & 30 & $2 / 2$ & 93 & $2 / 2$ & 95 & 2/amp & 82 & 1.16 & 28 & A \\
\hline 168 & $3 / 4$ & 24 & $3 / 3$ & 10 & $3 / 1$ & 19 & $4 / 4$ & 20 & 1.24 & 26 & A \\
\hline 171 & $2 / 3$ & 52 & $2 / 1$ & 67 & $3 / 1-2$ & 70 & $2 / 5-7$ & 90 & 1.09 & 22 & A \\
\hline \multirow[t]{2}{*}{179} & $1 / 2$ & 66 & $2 / 1$ & 58 & $4 / 4$ & 24 & $3 / 4$ & 30 & 1 & 11 & A \\
\hline & $2 / 4$ & 25 & & & & & $5 / 7$ & 19 & & & \\
\hline 186 & $2 / 3$ & 80 & $2 / 2$ & 99 & $2 / 1$ & 85 & $2 / 5-6$ & 81 & 1 & 4 & A \\
\hline \multirow[t]{2}{*}{189} & $3 / 5$ & 80 & $3 / 3$ & 29 & $2 / 2$ & 25 & $4 / 5$ & 80 & 1.46 & 3 & A \\
\hline & & & $4 / 4$ & 14 & $3 / 3$ & 45 & & & & & \\
\hline
\end{tabular}

$D$, dead; A, alive; amp, amplification.

*MYCN probe with centromere chromosome 2 or LAF gene as reference.

†1p36 gene region with centromere of chromosome 1 as reference.

${ }^{\ddagger} M L L$ gene for $11 \mathrm{q}$ region and centromere of chromosome 11 as reference.

$\$ 17 q 21,17 q 23$ (mpo) or 17q25 for 17q region with centromere of chromosome 17 or $17 p 13(p 53)$ as reference.

"Number of signals from reference gene (centromere or locus specific on $\mathrm{p}$ or $\mathrm{q}$ arm of the respective chromosome)/number of signals of the studied parameter: MYCN (2p),1p, 11q, and 17q

"Lost from follow up.

\section{Flow Cytometry}

The DNA index in 169 tumor samples was determined by flow cytometry with propidium-iodide; Modifit software (Beckton Dickinson, Heidelberg, Germany) was used for analysis. The cut-offs for ploidy were defined as follows: near-diploidy, 1 to 1.29; near-triploidy, 1.3 to 1.79; and near-tetraploidy, 1.8 to 2.19 .

\section{Quantitative Real Time PCR}

Total RNA was extracted from 38 primary tumors by using Tri-reagent (MRC, Cincinnati, $\mathrm{OH}$ ). One microgram of RNA was reverse transcribed by using the ImProm Reverse Transcription system (Promega Corporation, Madison, $\mathrm{WI}$ ), according to the manufacturer's recommended procedure. The cDNAs were cleaned by DNA Clean and Concentrator TM-5 Kit (Zymo Research Corporation, Orange, CA). cDNA concentrations were evaluated by NanoDrop ND-1000 Spectrophotometer (NanoDrop Technologies, Wilmington, DE).

From each sample, 20 ng was used for quantitative real time PCR. We measured MYCN and GAPDH (reference gene) levels by using the LightCycler (Roche Diagnostics $\mathrm{GmbH}$, Manheim, Germany). For MYCN gene we used Platinum SYBR Green qPCR Supermix UDG and for the 
Table 2. Clinical and Genetic Data According to MYCN Status

\begin{tabular}{|c|c|c|c|c|}
\hline Variables & 2p/MYCN gain* 25 (14) & MYCN amplified ${ }^{\dagger} 31(18)$ & MYCN balanced ${ }^{\ddagger} 121(68)$ & $P$ \\
\hline Male & $12(48)$ & $21(68)$ & $69(57)$ & NS \\
\hline Age, median, yr & 3.9 & 2.7 & 2.8 & NS \\
\hline \multicolumn{5}{|l|}{ Age, yr } \\
\hline$<1$ & $3(12)$ & 1(3) & $49(40)$ & \\
\hline$>1$ & $22(88)$ & $30(97)$ & $72(60)$ & $<0.001$ \\
\hline \multicolumn{5}{|l|}{ Stage } \\
\hline $1,2,4 \mathrm{~s}$ & $2(8)$ & $0(0)$ & $56(46)$ & \\
\hline 3,4 & $23(92)$ & $31(100)$ & $65(54)$ & $<0.001$ \\
\hline \multicolumn{5}{|l|}{ DNA index } \\
\hline Near $2 n / 4 n$ & 20/24 (83) & $27 / 31(87)$ & 77/114 (68) & 0.02 \\
\hline Near 3n & $4 / 24(17)$ & 4/31 (13) & $37 / 114(32)$ & 0.04 \\
\hline Del 1p & $9 / 25(36)$ & $18 / 30(60)$ & $29 / 119(24)$ & $<0.001$ \\
\hline Del 11q & $16 / 24(67)$ & $6 / 27(22)$ & 24/104 (23) & $<0.001$ \\
\hline Gain 17q & 19/24 (79) & $20 / 27(74)$ & $33 / 105(31)$ & $<0.001$ \\
\hline
\end{tabular}

Values given as $n(\%)$ unless stated otherwise. The cohort was divided into three groups according to MYCN status; $\chi^{2}$ test and analysis of variance were used to compare significance of differences in variables between groups.

*Extra copies of MYCN gene up to fourfold relative to chromosome 2 (reference gene: centromere 2 and/or LAF).

${ }^{+}$More than fourfold MYCN signals relative to chromosome 2.

¥Balanced number of MYCN and reference gene (centromere 2 and/or LAF).

GAPDH gene, we used Taqman probe and Platinum Quantitative PCR Supermix (Invitrogen, Paisley, Scotland, UK). To minimize the probability of contamination real time RTPCR reactions were performed in the CleanSpot PCR/UV station (Coy Laboratory Products, Grass Lake, MI). Primer sequences for MYCN were as follows: forward, 5'AGCCCTGCTTCTACCCGGAC-3'; reverse, 5'-GCTGGGTCACGGAGATGCTG-3'. Primer sequences for GAPDH gene and probe were as follows: forward, 5'-CAACAGCCTCAAGATCATCAGC-3'; reverse, 5'- CTCATGACCACAGTCCATGCCA-3'; GAPDH-probe: 5'-(FAM) CCTGGCCAAGGTCATCCATGACAAC (TAMRA)-3'. All samples were performed in duplicates. MYCN gene expression of each tumor was categorized as low or high by dichotomizing around the median PCR ratio obtained.

\section{Statistical Analysis}

We used the $\chi^{2}$ test and analysis of variance to compare the significance of differences in variables between groups. Kaplan-Meier estimates for event-free survival (EFS) and overall survival (OS) were calculated and compared by log-rank test. A $P$ value of $<0.05$ was considered statistically significant. A stepwise Cox regression model was applied, incorporating the genetic parameters MYCN (in the three categories: gain, balanced, and amplified), 1q, 11q, and $17 q$ regions. Relapse and death from disease were counted as events. Death resulting from toxicity was not counted as an event, but censored for the OS analysis. The eight patients analyzed after relapse were not taken in account for survival analysis. Three patients lost from follow up were included for biological characterization only.

\section{Results}

Extra copies of the MYCN gene were identified in 25 (14\%) patients, MYCN amplified in 31 (18\%) patients, and MYCN balanced in 121 (68\%) of the 177 patients with neuroblastoma included in the study. Twenty of 25 cases of the $2 p / M Y C N$ gain samples had one or two extra gene copies of MYCN relative to chromosome 2, and five patients had three extra copies. Ten of these samples were also tested by MLPA, which confirmed an enlarged region of gain including genes adjacent to the MYCN gene, proximal: RTN4, ALK, and distal: DDX1, NAG, and TMEM18 (Figure 1A). The smallest region of gain was represented by $A L K, M Y C N$, and DDX1 genes. FISH with $A L K$ probe on $2 \mathrm{p} 23$ was performed in the 15 cases when DNA was not available for MLPA analysis. In all of these instances, an identical copy number for MYCN and ALK genes was detected, confirming the co-gain of these two genes in our series (Figure 1B). Table 1 shows that 23 of the 25 2p/MYCN gain samples harbored at least one additional segmental aberration in eight cases, 2 in 10 cases, three in five cases, and, in two of the samples, none of the three regions, $1 p, 11 q$, and $17 q$ were found to be aberrant.

Table 2 summarizes the clinical and genetic data according to MYCN status. MYCN balanced tumors occurred more often in younger patients ( $<12$ months), whereas $2 \mathrm{p} / \mathrm{MYCN}$ gain and MYCN amplified tumors were seen in older patients ( $>12$ months; $P<0.001$ ). Advanced disease (stages 3 to 4 ) predominated in the $2 p / M Y C N$ gain group (92\%) and the MYCN amplified group (100\%) compared with the MYCN balanced group in which clinical stage was similarly distributed: $46 \%$ of patients with stage 1,2 , and $4 \mathrm{~s}$, and $54 \%$ with stages 3 and $4(P<0.001)$. DNA index was obtained from 169 patients. Near diplo/tetrapolid and near triploid tumors were almost equally distributed within $2 \mathrm{p} / \mathrm{MYCN}$ gain and MYCN amplified groups, but significantly different from the MYCN balanced group $(P=0.02$ and $P=0.04$, respectively). The $2 \mathrm{p} / \mathrm{MYCN}$ gain group was characterized by a significantly higher rate of segmental loss of the $11 q$ region (67\%) compared with the MYCN amplified group (22\%) and the MYCN balanced group (23\%; $P<$ $0.001)$. The rate of $17 q$ region gain was similar in the 2p/MYCN gain and MYCN amplified groups (79\% and $74 \%$, respectively) and significantly lower in the MYCN 
balanced group (31\%; $P<0.001)$. Deletions in the $1 p$ region were more frequent in the MYCN amplified group $(P<0.001)$. By MLPA, the most frequent segmental aberration found was $+17 q$ in nine cases, followed by $11 q^{-}$in seven cases, $3 p^{-}$in four cases, $1 p^{-}$in three cases, $+7 q$ in two cases, and $9 p^{-}$in one case. Numerical alterations were as follows: +7 in three cases, +17 in one case, and -3 in one case.

The median follow up of our cohort was 80 months, and relapse occurred in 60 of the 174 patients: 48 in stage 4 , 11 in stage 3, and one in stage 4s. Five-year EFS was similar for the 2p/MYCN gain and MYCN amplified groups $(40 \% \pm 13 \%$ and $28 \% \pm 9 \%$, respectively; $P=0.18)$ and significantly higher in the MYCN balanced group $(78 \% \pm$ $4 \% ; P<0.001$; Figure 2A). The 5-year OS was $51 \% \pm$ $14 \%$ in the $2 p / M Y C N$ gain group, $85 \% \pm 4 \%$ in the MYCN balanced group, and $34 \% \pm 10 \%$ in the MYCN amplified group. The difference between the $2 \mathrm{p} / \mathrm{MYCN}$ gain group and both the MYCN balanced group $(P=0.003)$ and MYCN amplified group were significant $(P=0.025$; Figure $2 \mathrm{~B}$ ). EFS and OS of the $2 \mathrm{p} / \mathrm{MYCN}$ gain group did not differ significantly whether associated or not with an additional single genetic marker alteration such as $11 \mathrm{q}$ loss (Figure 3, A and B), $1 p$ del, or $17 q$ gain. Tumors having $2 p / M Y C N$ gain without $17 q$ gain showed a better, but not statistically significant, outcome than those with segmental $17 q$ gain, probably due to the small size of the cohort (Table 3).

To investigate the possible association between MYCN copy number and expression, 38 of the nonamplified neuroblastoma patient samples were evaluated. The median PCR ratio value was 260. Low and high MYCN expression NB were compared between tumors with a balanced number of MYCN gene and with MYCN gene extra copies. The $\chi^{2}$ test was applied to analyze this association and no statistically significant correlation was noted ( $P=0.637$; Table 4).

The stepwise Cox regression model was used, incorporating the three MYCN groups (gain, balanced, and amplified), 1q, 11q, and 17q. In the final stage, the remaining predictors of adverse outcome were $\mathrm{MYCN}$ amplification (hazards ratio: $3.2 ; P=0.006$ ) and $11 q$ loss (hazards ratio: $3.7 ; P<0.001$ ).

\section{Discussion}

Since FISH was performed on all NB samples, we were able to determine the MYCN status according to the established criteria. ${ }^{30}$ MYCN amplification was detected in $18 \%$ of the tumors, which is lower than the $20 \%$ to $25 \%$ reported in the literature. ${ }^{38,39}$ Tumors with $2 \mathrm{p} / \mathrm{MYCN}$ gain accounted for $14 \%$ of the sample. Reported rates for the few additional copies of the MYCN gene range from $6 \%$ to $13 \%$; most of the studied tumors had one to three extra copies. ${ }^{31-33}$ In accordance with these studies, 20 of the 25 patients in this group had one or two extra copies of the MYCN gene, and in another five patients, three extra copies were found.

Previous studies have suggested that the MYCN oncogene is amplified by replication-excision or at a distant
A EFS

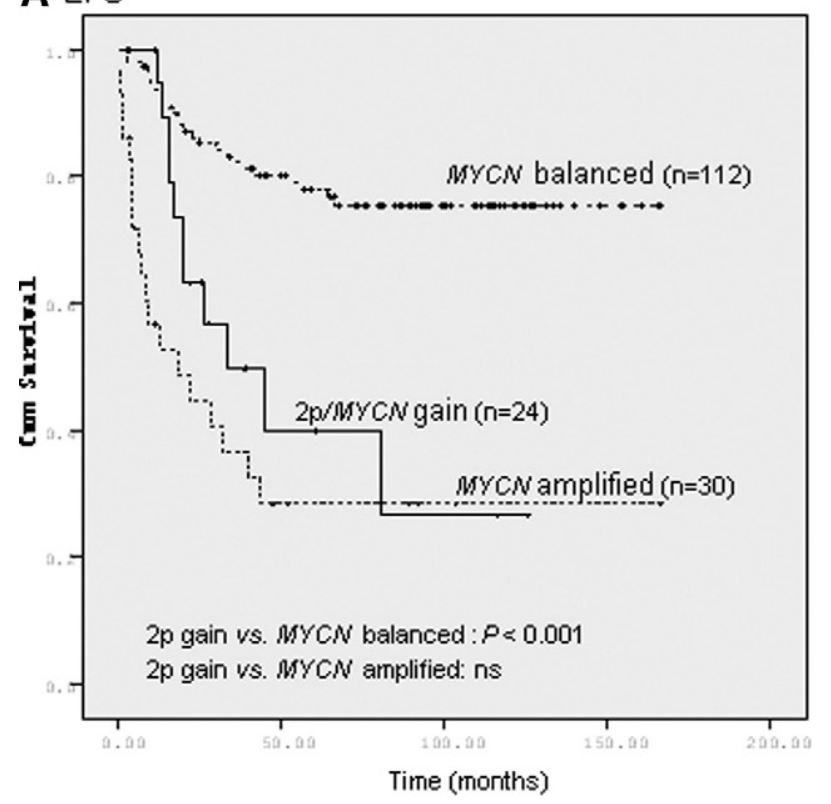

B os

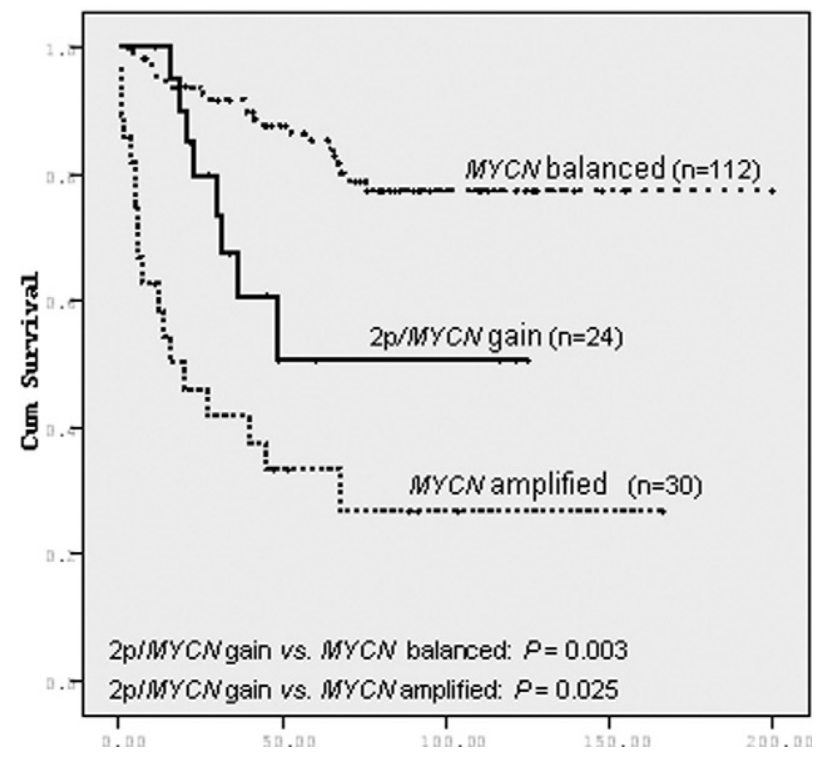

Figure 2. EFS and OS for the whole cohort according to $M Y C N$ status. A: 5-year EFS MYCNbalanced: balanced number of $M Y C N$ and cep2/LAF genes: $78 \% \pm 4 \% ; 2 \mathrm{p} / M Y C N$ gain: $40 \% \pm 13 \%$; and $M Y C N$ amplified: $29 \% \pm 8 \%$. B: 5-year OS MYCN balanced: $85 \% \pm 4 \% ; 2$ p gain: $51 \% \pm 14 \%$; and $M Y C N$ amplified: $34 \% \pm 10 \%$.

region (translocated) from the resident site of the gene. ${ }^{39}$ Another, rarer, phenomenon is the in situ duplication of the MYCN gene at its own locus, 2p24, as shown in two cell lines. ${ }^{40}$ However, the most frequent finding is the acquisition of a few additional copies of MYCN through the formation of an iso(2p), or as a result of unbalanced translocations of chromosome $2 p$, which harbors the MYCN gene, with different partner chromosomes. ${ }^{41,42}$ Studies applying comparative genomic hybridization, ${ }^{43,44}$ array-comparative genomic hybridization, ${ }^{44-47}$ and single-nucleotide polymorphism studies ${ }^{48}$ could demonstrate that extra copies of MYCN gene are often accompanied by a set of adjacent 
A EFS

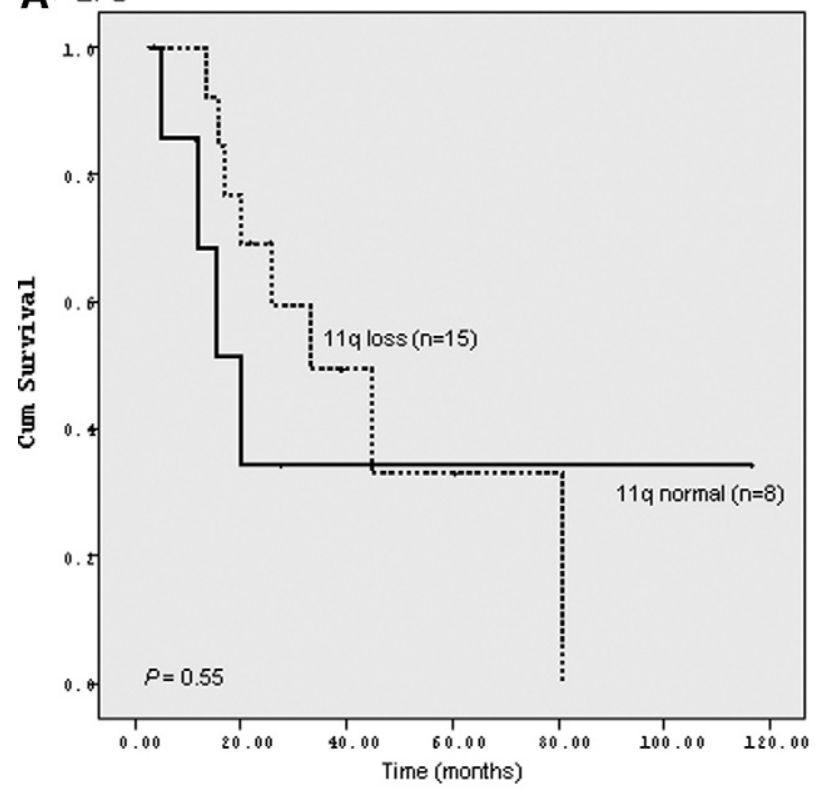

B os

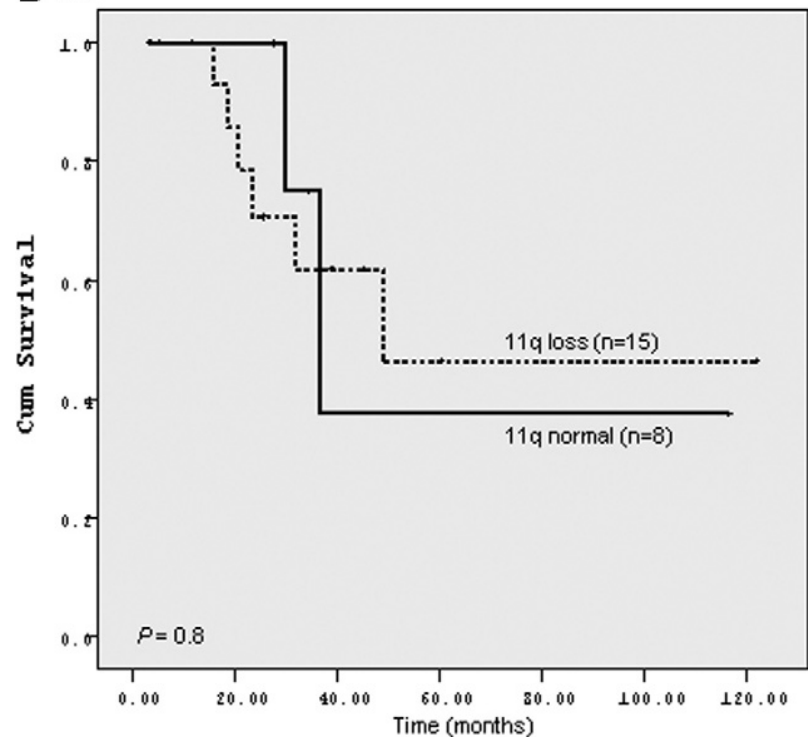

Figure 3. EFS and OS of $2 \mathrm{p} / M Y C N$ gain group according to $11 \mathrm{q}$ status. A: 5-year EFS 11q normal: 34\% $\pm 2 \%$; 11q loss: $33 \% \pm 17 \%$. B: 5 -year OS $11 q$ normal: $38 \% \pm 29 \%$; 11 q loss: $46 \% \pm 16 \%$.

genes, thus supporting the suggestion that they may be the result of unbalanced translocations. In this study MLPA was performed mainly in the MYCN gain group only to confirm the partial gain of $2 p$ region harboring $M Y C N$ gene. Accordingly, our MLPA results showed that all but one of the 10 tested samples had also a gain of $A L K, D D X 1$, and NAG genes (Figure 1A), all of them localized adjacent to $M Y C N$, defining a $2 \mathrm{p}$ gain. ${ }^{30}$ Recently, in addition to gain or coamplification, somatic and germ line mutations of the ALK gene contributing to neuroblastoma oncogenesis have been reported in advanced neuroblastoma tumors correlating with a poor outcome. ${ }^{49-51}$ It has been suggested that given that the down-regulation of $A L K$ expression suppresses the proliferation of neuroblastoma cells, it may represent a therapeutic target for this disease. Furthermore,
Table 3. Five-year EFS and OS of $2 \mathrm{p} / \mathrm{MYCN-g}$ Group in Relation to Additional Markers Changes

\begin{tabular}{ccccc}
\hline 2p/MYCN gain & 5 -yr EFS & $P$ & 5 -yr OS & $P$ \\
\hline $1 \mathrm{p}$ & & & & \\
no del $(n=15)$ & $55 \pm 20$ & $0.3 \mathrm{NS}$ & $54 \pm 20$ & $0.9 \mathrm{NS}$ \\
del ${ }^{\dagger}(n=9)$ & $43 \pm 15$ & & $55 \pm 15$ & \\
$11 \mathrm{q}$ & & & & \\
no del $(n=8)$ & $34 \pm 20$ & $0.6 \mathrm{NS}$ & $46 \pm 16$ & $0.8 \mathrm{NS}$ \\
del $(n=15)$ & $33 \pm 17$ & & $38 \pm 29$ & \\
$17 \mathrm{q}$ & & & & \\
no gain $(n=5)$ & $60 \pm 22$ & $0.8 \mathrm{NS}$ & $67 \pm 28$ & $0.4 \mathrm{NS}$ \\
gain $(n=18)$ & $26 \pm 4$ & & $42 \pm 16$ & \\
\hline
\end{tabular}

No significant difference could be observed with or without additional of single marker alteration.

*no deleted.

tdeleted.

$A L K$ has been identified in one study as a major familial neuroblastoma predisposition gene. ${ }^{52}$

As in earlier reports, the $2 \mathrm{p} / \mathrm{MYCN}$ gain group was strongly associated with $11 \mathrm{q}$ loss, and MYCN amplification was often accompanied by $1 p$ deletion. In addition, we found that $76 \%$ of the $2 \mathrm{p} / \mathrm{MYCN}$ gain group had advanced (stages 3 to 4 ) disease as noted by Spitz et al. ${ }^{32}$

Patients with 2p/MYCN gain had a poor 5-year EFS, similar to that of the MYCN amplified group and differing significantly from the MYCN balanced group (5-year EFS $2 \mathrm{p} / \mathrm{MYCN}$ gain versus MYCN balanced, $40 \% \pm 13 \%$ vs. $78 \% \pm 4 \%$, respectively; $P<0.001$; Figure $2 \mathrm{~A}$ ), consistent with previous observations. ${ }^{32}$ However, the 5-year OS of the $2 \mathrm{p} / \mathrm{MYCN}$ gain group was intermediate, between that of the MYCN amplified group (51 $\pm 14 \%$ vs. $34 \% \pm 10 \%$, respectively; $P=0.025)$ and the MYCN balanced group $(51 \% \pm 14 \%$ vs. $85 \% \pm 4 \%$, respectively; $P=0.003$; Figure 2B). Taken together, these data indicate that although both $2 \mathrm{p} / \mathrm{MYCN}$ gain and $M Y C N$ amplified neuroblastoma point to a poor prognosis, the former progresses less rapidly.

There is still some speculation as to whether low-level MYCN gene gain affects the clinical behavior of the tumor by increasing MYCN expression levels. ${ }^{31,32}$ Some studies found no direct correlation between MYCN copy number and the level of MYCN expression, ${ }^{53}$ or association of

Table 4. $M Y C N$ Gene Expression Values of 38 Nonamplified NB Patients

\begin{tabular}{|c|c|c|}
\hline \multicolumn{2}{|c|}{ MYCN expression* $n=38$} & \multirow[b]{2}{*}{$P$} \\
\hline & $\mathrm{n}(\%)$ & \\
\hline \multicolumn{3}{|l|}{ Low $(<260)^{\dagger}$} \\
\hline MYCN-b & $17(89)$ & \\
\hline MYCN-g§ & $2(11)$ & \\
\hline & & $\begin{array}{l}0.6 \\
\text { NS }\end{array}$ \\
\hline \multicolumn{3}{|l|}{ High $(>260)$} \\
\hline MYCN-b & $15(79)$ & \\
\hline MYCN-g & $4(21)$ & \\
\hline
\end{tabular}

${ }^{*} M Y C N$ gene expression of each tumor was categorized as low or high by dichotomizing around the median PCR ratio.

${ }^{\dagger}$ Median PCR ratio: 260.

¥Balanced number of MYCN gene and chromosome 2.

ङExtra copies of MYCN gene up to 4-fold relative to chromosome 2 as defined by ENQUA. 
the level of MYCN expression with any other prognostic factors. ${ }^{54}$ In addition, genes proximal and distal to MYCN were found to be highly expressed when using comparative expressed sequence hybridization. ${ }^{55} \mathrm{We}$, too, failed to detect any significant correlation between MYCN status and MYCN expression levels $(P=0.637$; Table 4$)$.

Segmental imbalance of the $2 \mathrm{p} 24$ region harboring extra copies of the MYCN gene is a relatively common event in advanced-stage neuroblastoma. A report of two cases of neuroblastoma without amplification at diagnosis but with low-level gain of the MYCN gene evolving into MYCN amplification at relapse have been described in the literature. ${ }^{33-34}$ Valent et $\mathrm{al}^{31}$ have shown simultaneous MYCN gain and amplification. The detailed study of these cases supplied information about several different mechanisms leading to increased MYCN copy number. However, the issues still being debated are whether gain is a necessary prerequisite for amplification, whether it is an independent event in NB, and whether it is a specific phenomenon of NB tumors or a general mechanism by which tumor cells can acquire selective growth advantage. As Valent et al ${ }^{31}$ proposed, it is necessary to find more cases of primary NB with simultaneous gain and amplification to clarify the significance of this characteristic. In our series we detected only one case with simultaneous gain and amplification, and it was included in the MYCN amplified group. Spitz et al $(2004)^{32}$ suggested that owing to the close association of MYCN gain with $11 \mathrm{q}$ loss, and the inverse correlation between this alteration and MYCN amplification, the presence of extra copies of MYCN is probably an independent late event in advanced neuroblastoma not leading to MYCN amplification, and may not have a substantial prognostic influence. Indeed, the inverse correlation between 11q loss and MYCN amplification has already been reported as a frequent finding in high-stage neuroblastoma suggesting a poor prognosis. ${ }^{18,56,57}$ To determine the possible influence of the strong association of $2 p / M Y C N$ gain with segmental $11 q$ alterations on disease outcome, we performed a Kaplan-Meier analysis in the $2 p / M Y C N$ gain group, comparing patients with and without $11 \mathrm{q}$ loss. We found no statistical significance between subgroup differences in 5-year EFS $(33 \% \pm 17 \%$ vs. $34 \% \pm 20 \%$, respectively; $P=0.6$; Figure $3 \mathrm{~A}$ ) or 5 -year OS ( $46 \% \pm 16 \%$ vs. $38 \% \pm 29 \%$, respectively; $P=$ 0.8 ; Figure 3B). These data suggest that poor outcome of $2 p / M Y C N$ gain group is apparently unrelated to the strong association with $11 \mathrm{q}$ deletions. However, the small sample of patients did not allow for a statistically robust conclusion, and this assumption requires further confirmation in a larger study. We have previously identified a group of tumors (10 of which were included in the present cohort) with $11 \mathrm{q}$ segmental loss characterized by $\operatorname{der}(11) t(11,17)$ on SKY ${ }^{58,59}$ Although associated with a poor prognosis, these patients had a distinct course of slower progression than $\mathrm{MYCN}$-amplified tumors. Nonrandom $\mathrm{t}(11 ; 17)$ has previously been reported to be one of the mechanisms underlying $11 \mathrm{q}$ loss and $17 \mathrm{q}$ gain by tumors. ${ }^{60,61}$ Only 3 of 10 tumors from our series had extra copies of MYCN gene.
In conclusion, our data show that neuroblastoma tumors characterized by $2 p / M Y C N$ gain region are associated with a low, though less rapidly progressive, EFS rate similar to that of neuroblastoma with MYCN amplification. This behavior does not seem to be influenced by $11 \mathrm{q}$ deletions, 5 -year survival of patients with and without $11 \mathrm{q}$ deletions were similar within the $2 \mathrm{p} / \mathrm{MYCN}$ gain group; neither does it seem to be related to the previously described group harboring $11 \mathrm{q}$ deletions through $\mathrm{t}(11 ; 17)$ or other single studied segmental alterations such as $1 p$ deletions or $17 q$ gain (Table 3 ).

The evaluation of MYCN status by FISH is still the gold standard for neuroblastoma characterization. The use of a $2 \mathrm{p}$ specific probe in addition to $2 \mathrm{q}$ signals (optionally a centromeric probe), simultaneously, is recommended by the International Neuroblastoma Risk Group Biology Committee $^{30}$ to clarify the presence of a chromosome $2 p$ gain versus a restricted $M Y C N$ gain. Following this recommendation, we could identify the $2 p / M Y C N$ gain group in our cohort, characterized by high frequency of cooccurrence of other segmental alterations and associated with a poor outcome. Altogether, these data suggest that the presence at diagnosis of extra copies of MYCN gene in nonamplified tumors may reveal an underlying genetic pattern of combined segmental and numerical alterations and subsequently help to understand the behavior of these tumors.

\section{Acknowledgments}

We thank Professor Peter Ambros for his constructive criticism. We also thank Ms. Ilana Gelernter for her help in the statistical analysis and Mrs. Sara Dominitz for editorial assistance.

\section{References}

1. Maris JM, Matthay KK: Molecular biology of neuroblastoma. J Clin Oncol 1999, 17:2264-2279

2. Brodeur GM: Neuroblastoma: biological insights into a clinical enigma. Nat Rev Cancer 2003, 3:203-216

3. London WB, Castleberry RP, Matthay KK, Look AT, Seeger RC Shimada H, Thorner P, Brodeur G, Maris JM, Reynolds CP, Cohn S: Evidence for an age cut-off greater 365 days for than neuroblastoma risk group stratification in the Children's Oncology Group. J Clin Oncol 2005, 23:6459-6465

4. Brodeur GM, Pritchard J, Berthold F, Carlsen NLT, Castel V, Castelberry RP, De Bernardi B, Evans AE, Favrot M, Hedborg F, Kaneko M, Kemshead J, Lampert F, Lee REJ, Look AT, Pearson ADJ, Philip T, Roald B, Sawada T, Seeger RC, Tsuchida Y, Voûte PA: Revisions of the international criteria for neuroblastoma diagnosis, staging, and response to treatment. J Clin Oncol 1993, 11:1466-1477

5. Shimada H, Ambros I, Dehner L, Hata J, Joshi VV, Roald B, Stram DO Gerbing RB, Lukens JN, Matthay KK, Castleberry RP: The International Neuroblastoma Pathology Classification (the Shimada System). Cancer 1999, 86:364-372

6. Look AT, Hayes FA, Shuster JJ, Dougalss EC, Castelberry RP, Bowman LC, Smith El, Brodeur GM: Clinical relevance of tumor cell ploidy and $\mathrm{N}$-myc gene amplification in childhood neuroblastoma: a Pediatric Oncology Group study. J Clin Oncol 1991, 9:581-591

7. Ladenstein R, Ambros IM, Potschger U, Amann G, Urban C, Fink FM, Schmitt K, Jones R, Slociak M, Schilling F, Ritter J, Berthold F, Gadner $\mathrm{H}$, Ambros PF: Prognostic significance of DNA di-tetraploidy in neuroblastoma. Med Pediatr Oncol 2001, 36:83-92 
8. Brodeur GM, Seeger RC, Schwab M, Varmus HE, Bishop JM: Amplification of N-myc in untreated human neuroblastoma correlate with advance disease stage. Science 1984, 224:1121-1124

9. Seeger RC, Brodeur GM, Sather H, Dalton A, Siegel SE, Wong KY, Hammond D: Association of multiple copies of the N-myc oncogene with rapid progression of neuroblastoma. N Engl J Med 1985, 313:1111-1116

10. Maris JM, White PS, Beltinger CP, Sulman EP, Castleberry RP, Shuster JJ, Look AT, Brodeur GM: Significance of chromosome 1p loss of heterozygosity in neuroblastoma. Cancer Res 1995, 55:4664-4669

11. Gehring M, Berthold F, Edler L, Schwab M, Amler LC: The 1p deletion is not a reliable marker for the prognosis of patients with neuroblastoma. Cancer Res 1995, 15:5366-5399

12. Caron $\mathrm{H}$, van Sluis $\mathrm{P}$, de Kraker J, Bökkerink J, Egeler M, Laureys G, Slater R, Westerveld A, Voûte P, Versteeg R: Allelic loss of chromosome $1 \mathrm{p}$ as a predictor of unfavorable outcome in patients with neuroblastoma. N Engl J Med 1996, 334:225-230

13. Lastowska M, Cotterill S, Pearson ADJ, Roberts P, McGuckin A, Lewis I, Bown N: Gain of chromosome arm 17q predicts unfavourable outcome in neuroblastoma patients. Eur J Cancer 1997, 33:1627-1633

14. Bown N, Cotterill S, Lastowska M, O'Neill S, Pearson AD, Plantaz D, Meddeb M, Danglot G, Brinkschmidt C, Christiansen H, Laureys G, Speleman F, Nicholson J, Bernheim A, Betts DR, Vandesompele J, Van Roy N: Gain of chromosome arm 17q and adverse outcome in patients with neuroblastoma. N Engl J Med 1999, 340:1954-1961

15. Bown N, Lastowska M, Cotterill S, O'Neill S, Ellershaw C, Roberts P, Lewis I, Pearson AD, UK Cancer Cytogenetics Group, UK Children's Cancer Study Group: 17q gain in neuroblastoma predicts adverse clinical outcome. Med Pediatr Oncol 2001, 36:14-19

16. Spitz R, Hero B, Ernestus K, Berthold F: Gain of distal chromosome arm $17 q$ is not associated with poor prognosis in neuroblastoma. Clin Cancer Res 2003, 9:4835-4840

17. Spitz R, Hero B, Ernestus K, Berthold F: Deletions in chromosome arms $3 p$ and $11 q$ are new prognostic markers in localized and $4 s$ neuroblastoma. Clin Cancer Res 2003, 9:52-58

18. Plantaz D, Vandesompele J, Van Roy N, Lastowska M, Bown N, Combaret V, Favrot MC, Delattre O, Michon J, Bénard J, Hartmann O, Nicholson JC, Ross FM, Brinkschmidt C, Laureys G, Caron H, Matthay KK, Feuerstein BG, Speelman F: Comparative genomic hybridization $(\mathrm{CGH})$ analysis of stage 4 neuroblastoma revealed high frequency of $11 q$ deletion in tumors lacking MYCN amplifications. Int J Cancer 2001, 91:680-686

19. Attiyeh EF, London WB, Mossé YP, Wang Q, Winter C, Khazi D, McGrady PW, Seeger RC, Look AT, Shimada H, Brodeur GM, Cohn SL, Matthay KK, Maris JM, Children's Oncology Group: Chromosome $1 \mathrm{p}$ and $11 \mathrm{q}$ deletions and outcome in neuroblastoma. N Engl J Med 2005, 353:2243-2253

20. Lastowska M, Viprey V, Santibanez-Koref M, Wappler I, Peters H, Cullinane C, Roberts P, Hall AG, Tweddle DA, Pearson ADJ, Lewis I, Burchill SA, Jackson MS: Identification of candidate genes involved in neuroblastoma progression by combining genomic and expression microarrays with survival data. Oncogene 2007, 1-13

21. Cohn SL, Pearson ADJ, London WB, Monclair T, Ambros PF, Brodeur GM, Faldum A, Hero B, lehara T, Machin D, Mosseri V, Simon T, Garaventa A, Castel V, Matthay KK: The International Neuroblastoma Risk Group (INRG) Classification System: an INRG Task Force Report. J Clin Oncol 2009, 27:289-297

22. Schleiermacher G, Michon J, Huon I, Duboisd'Enghien C, Klijanienko J, Brisse H, Ribeiro A, Mosseri V, Rubie H, Munzer C, Thomas C, Valtau-Couanet D, Avrignon A, Plantaz D, Delattre O, Couturier J: Chromosomal $\mathrm{CGH}$ identifies patients with higher risk of relapse in neuroblastoma without MYCN amplification. Br J Cancer 2007, 97:238-246

23. Janoueix-Lerosey I, Schleiermacher G, Michels E, Veronique Mosseri V, Ribeiro A, Lequin D, Vermeulen J, Couturier J, Peuchmaur M, Valent A, Plantaz D, Rubie H, Valteau-Couanet D, Thomas C, Combaret C, Rousseau R, Eggert A, Michon J, Speleman F, Delattre O: Overall genomic pattern is a predictor of outcome in neuroblastoma. J Clin Oncol 2009, 27:1026-1033

24. Ohali A, Avigad S, Ash S, Goshen Y, Luria D, Feinmesser M, Zaizov $\mathrm{R}$, Yaniv I: Telomere length is a prognostic factor in neuroblastoma. Cancer 2006, 15:1391-1399

25. Schwab M, Ellison J, Busch M, Rosenau W, Varmus HE, Bishop JM: Enhanced expression of the human gene N-myc consequent to am- plification of DNA may contribute to malignant progression of neuroblastoma. Proc Natl Acad Sci USA 1984, 81:4940-4944

26. Hogarty MD, Brodeur GM: Wild type sequence of MYCN in neuroblastoma cell lines. Int J Cancer 1999, 80:630-631

27. Ambros IM, Benard J, Boavida M, Bown N, Caron H, Combaret V Couturier J, Darnfors C, Delattre O, Freeman-Edward J, Gambini C, Gross N, Hattinger CM, Luegmayr A, Lunec J, MartinssonT, Mazzoco K, Navarro S, Noguera R, O'Neill S, Pötschger U, Rumpler S, Speleman F, Tonini GP, Valent A, Van Roy N, Amann G, De Bernardi B, Kogner P. Ladenstein R, Michon J, Pearson ADJ, Ambros PF: Quality Assessment of genetic markers used for therapy stratification. J Clin Oncol 2003, 21:2077-2084

28. Shapiro DN, Valentine MB, Rowe ST, Sinclair AE, Suublett JE, Roberts WM, Look AT: Detection of N-myc gene amplification by fluorescence in situ hybridization. Am J Pathol 1993, 142:1339-1346

29. Theissen J, Boensch M, Spitz R, Betts D, Stegmaier S, Christiansen H, Niggli F, Schilling F, Schwab M, Simon T, Westermann F, Berthold $F$, Hero B: Heterogeneity of the MYCN oncogene in neuroblastoma. Clin Cancer Res 2009, 15:2085-2090

30. Ambors PF, Ambros IN, Brodeur GM, Haber M, Jhan J, Nakagawara A, Schleiermacher G, Speleman F, Spitz R, London WB, Pearson ADJ, Maris JM: International consensus for neuroblastoma molecular diagnostic: report from the International Neuroblastoma Risk Group (INRG) Biology Committee. Br J Cancer 2009, 100:1471-1482

31. Valent A, Le Roux G, Barrois M, Terrier-Lacombe MJ, Valteau-Couanet D, Léon B, Spengler B, Lenoir G, Bénard J, Bernheim A: MYCN gene overrepresentation detected in primary neuroblastoma tumour cells without amplification. J Patholy 2002, 198:495-501

32. Spitz R, Hero B, Skowron M, Ernestus K, Berthold F: MYCN-status in neuroblastoma: characteristics of tumors showing amplification, gain and non-amplification. Eur J Cancer 2004, 40:2753-2759

33. Stallings RL, Carty P, McArdle L, Mullarkey M, McDermott M, O'Meara $A$, Ryan E, Catchpoole D, Breatnach F: Evolution of unbalanced gain of distal chromosome 2p in neuroblastoma. Cytogenet Genome Res 2004, 106:49-54

34. Noguera R, Cañete A, Pellín A, Ruiz A, Tasso M, Navarro S, Castel V, Llombart-Bosch A: MYCN gain and MYCN amplification in a stage $4 S$ neuroblastoma. Cancer Genet Cytogenet 2003, 140:157-161

35. Stark B, Jeison M, Gobuzov R, Grug H, Glaser-Gabay L, Luria D, El-Hasid R, Ben Harush M, Avrahami G, Fisher S, Stein J, Zaizov R, Yaniv I: Near haploid childhood acute lymphoblastic leukemia masked by hyperdiploid line: detection by fluorescence in situ hybridization. Cancer Genet Cytogenet 2001, 128:108-113

36. Schouten JP, McElgunn CJ, Waajer R, Zwijnenburg D, Diepvens F, Pals G: Relative quantification of 40 nucleic acid sequences by multiplex ligation-dependent probe amplification. Nucleic Acid Res 2002, 30:e57

37. van Dijk MC, Rombout PD, Boots-Sprenger SH, Straatman $H$, Bernsen M, Ruiter DJ, Jeuken JW: Multiplex-ligation-dependent probe amplification for the detection of chromosomal gain and losses in formalin-fixed tissue. Diagn Mol Pathol 2005, 14:9-16

38. Schwab M: Oncogene amplification in solid tumors. Semin Cancer Biol 1999, 9:319-325

39. Savelyeva L, Schwab M: Amplification of oncogenes revisited: from expression profiling to clinical application. Cancer Letters 2001, 167:115-123

40. Corvi R, Savalyeva L, Schwab M: Duplication of N-myc gene at its resident site 2p24 may be a mechanism of activation alternative to amplification in human neuroblastoma cells. Cancer Res 1995, 55:3471-3474

41. Van Roy N, Van Limbergen H, Vandesompele J, Van Gele M, Poppe B, Laureys G, De Paepe A, Speleman F: Chromosome 2 short arm translocations revealed by M-FISH analysis of neuroblastoma cell lines. Med Pediatr Oncol 2000, 35:538-540

42. Valent A, Guillaud-Bataille M, Farra Ch, Lozach F, Spengler B, TerrierLacombe MJ, Valteau-Couanet D, Danglot G, Lenoir G, Brison O, Bénard J, Bernheim A: Alternative pathways of MYCN gene copy number increase in primary neuroblastoma tumors. Cancer Genet Cytogenet 2004, 153:10-15

43. Schleiermacher G, Janoueix-Lerosey I, Combaret V, Derré J, Couturier J, Aurias A, Delattre O: Combined 24-color karyotype and comparative genomic hybridization analysis indicates predominant rearrangements of early replicating chromosome regions in neuroblastoma. Cancer Genet Cytogenet 2003, 141:23-42 
44. Villamon E, Piqueras M, Mackintosh C, Alonso J, de Alava E, Navarro $\mathrm{S}$, Noguera R: Comparisson of different techniques for the detection of genetic risk-identifying chromosomal gains and losses in neuroblastoma. Virchows Arch 2008, 453:47-55

45. Chen Q-R, Bilke S, Khan J: High-resolution cDNA microarray-based comparative genomic hybridization analysis in neuroblastoma. Cancer Lett 2005, 228:71-81

46. Mossé YP, Greshock J, Weber BL, Maris JM: Measurement and relevance of neuroblastoma DNA copy number changes in the postgenome era. Cancer Lett 2005, 228:83-90

47. Spitz R, Oberthuer A, Zapatka M, Brors B, Hero B, Ernestus K, Oestreich J, Fischer M, Simon T, Berthold F: Oligonucleotide arraybased comparative genomic hybridization (aCGH) of 90 neuroblastomas reveals aberration patterns closely associated with relapse pattern and outcome. Genes Chromosomes Cancer 2006, 45:1130-1142

48. George RE, Attiyeh EF, Shuli L, Moreau LA, Neuberg D, Cheng L, Fox EA, Meyerson M, Diller L, Fortina P, Look AT, Maris JM: Genome-wide analysis of neuroblastomas using high-density single nucleotide polymorphism arrays. PLoS One 2007, 2:e255

49. Carén $\mathrm{H}$, Abel $\mathrm{F}$, Kogner $\mathrm{P}$, Martinsson T: High incidence of DNA mutations and gene amplifications of the ALK gene in advanced sporadic neuroblastoma tumors. Biochem J 2008, 416:153-159

50. Chen Y, Takita J, Choi YL, Kato M, Ohira M, Sanada M, Wang L, Soda M, Kikuchi A, Igarashi T, Nakagawara A, Hayashi Y, Mano H, Ogawa $\mathrm{S}$ : Oncogenic mutations of ALK kinase in neuroblastoma. Nature 2008, 455:971-974

51. Janoueix-Lerosey I, Lequin D, Brugières $L$, Ribeiro $A$, de Pontual $L$, Combaret V, Raynal V, Puisieux A, Schleiermacher G, Pierron G, Valteau-Couanet D, Frebourg T, Michon J, Lyonnet S, Amiel J, Delattre $\mathrm{O}$ : Somatic and germline activating mutations of the ALK kinase receptor in neuroblastoma. Nature 2008, 455:967-970

52. Mossé YP, Laudenslager M, Longo L, Cole KA, Wood A, Attiyeh EF, Laquaglia MJ, Sennett R, Lynch JE, Perri P, Laureys G, Speleman F, Kim C, Hou C, Hakonarson H, Torkamani A, Schork NJ, Brodeur GM, Tonini GP, Rappaport E, Devoto M, Maris JM: Identification of ALK as a major familial neuroblastoma predisposition gene. Nature 2008, 455:930-935
53. Cohn SL, London WB, Huang D, Katzenstein HM, Salwen HR, Reinhart T, Madafiglio J, Marshall GM, Norris MD, Haber M: MYCN expression is not prognostic of adverse outcome in advanced-stage neuroblastoma with nonamplified MYCN. J Clin Oncol 2000, 18:3604-3613

54. Tajiri T, Tanaka S, Higashi M, KinoshitaY, Takahashi $Y$, Tatsuta $K$ Sachiyo S: Biological diagnosis for neuroblastoma using the combination of highly sensitive analysis of prognostic factors. J Pediatr Surg 2006, 41:560-566

55. Stock C, Bozarsky E, Watzinger F, Poetschger U, Orel L, Lion T, Kowalska A, Ambros P: Genes proximal and distal to MYCN are highly expressed in human neuroblastoma as visualized by comparative expressed sequence hybridization. Am J Pathol 2008, 172:203-214

56. Guo C, White PS, Weiss MJ, Hogarty MD, Thompson PM, Stram DO, Gerbing R, Matthay KK, Seeger RC, Brodeur GM, Maris JM: Allelic deletion at 11q23 is common in MYCN single copy neuroblastomas. Oncogene 1999, 18:4948-4957

57. Guo C, White PS, Hogarty MD, Brodeur GM, Gerbing R, Stram DO, Maris JM: Deletion of $11 \mathrm{q} 23$ is a frequent event in the evolution of MYCN single-copy high-risk neuroblastomas. Med Pediatr Oncol 2000, 35:544-546

58. Stark B, Jeison M, Bar-Am I, Glaser-Gabay L, Mordoukh J, Luria D, Feinmeser M, Goshen Y, Stein J, Abramov A, Zaizov R, Yaniv I: Distinct cytogenetic pathways of advanced-stage neuroblastoma tumors, detected by spectral karyotyping. Genes Chromosomes Cancer 2002, 34:313-324

59. Stark B, Jeison M, Glaser-Gabay L, Bar-Am I, Mordoukh J, Ash SH, Atias D, Stein J, Zaizov R, Yaniv I: der(11)t(11;17): a distinct cytogenetic pathway of advanced stage neuroblastoma (NBL) detected by spectral karyotype (SKY). Cancer Lett 2003, 19:75-79

60. Lastowska M, Van Roy N, Bown N, Speelmanm F, Lunec J, Strachan $T$, Pearson ADJ, Jackson MS: Molecular cytogenetic delineation of 17q translocation breakpoints in neuroblastoma cell lines. Genes Chromosomes Cancer 1998, 23:116-122

61. Stallings RL, Carty P, McArdle L, Mullarkey M, McDermott M, Breatnach F, O'Meara A: Molecular cytogenetic analysis of recurrent unbalanced t $(11 ; 17)$ in neuroblastoma. Cancer Genet Cytogenet 2004, 154:44-51 